\title{
Evolution of artificial spawning sites for Atlantic salmon (Salmo salar) and sea trout (Salmo trutta): field studies and numerical modelling in Aurland, Norway
}

\author{
C. Hauer $(\mathbb{D} \cdot$ U. Pulg $\cdot$ F. Reisinger $\cdot$ P. Flödl
}

Received: 1 November 2019/Revised: 21 December 2019/Accepted: 29 December 2019/Published online: 27 January 2020

(C) The Author(s) 2020

\begin{abstract}
The presented study investigates the evolution of artificial gravel placements for Atlantic salmon and sea trout in Aurlandselva in Western Norway. Various monitoring methods have been applied including (i) quantifying the spatial extent and dynamics of spawning sites over the monitoring period, (ii) grain size distributions as well as (iii) applying numerical hydraulic and sediment transport modelling with the aim to test the predictability of such numerical tools. The spawning sites were not clogged by fine sediments, but were reshaped due to scouring and sediment transport. The scouring resulted in a volume loss of the gravel banks between 32 and $95 \%$ in the monitoring period of 5 years. The
\end{abstract}

Handling editor: Luigi Naselli-Flores

Electronic supplementary material The online version of this article (https://doi.org/10.1007/s10750-019-04173-1) contains supplementary material, which is available to authorized users.

C. Hauer $(\bowtie) \cdot$ F. Reisinger $\cdot$ P. Flödl

CD-Laboratory for Sediment Research and Management, Institute of Hydraulic Engineering and River Research,

Department of Water, Atmosphere and Environment,

University of Natural Resources and Life Sciences

Vienna, Muthgasse 107, 1190 Vienna, Austria

e-mail: christoph.hauer@boku.ac.at

U. Pulg

NORCE LFI, Norwegian Research Centre, Laboratorium for Freshwater Ecology and Inland Fisheries,

Nygårdsgaten 112, 5006 Bergen, Norway application of hydrodynamic-numerical modelling, however, showed that the modelling methods were not sufficient to predict erosion of the gravel or the site. The study showed that the areas are sensitive especially to local scale micro-topographical roughness elements. The complex three-dimensional hydraulic processes and the coarse substrate in the non-fluvial river environment makes it impracticable for multi-dimensional modelling to predict dynamics of gravel. A novel sediment criterion was introduced to estimate the near-bottom turbulence by relating the $d_{m}$ of introduced gravel compared to the $d_{90}$ of the bed surface substrate composition.

Keywords Spawning habitat restoration - Atlantic salmon · Anadromous brown trout - Sediment management $\cdot$ Gravel dynamics

\section{Introduction}

Spawning sites for salmonids are one of the key habitats in the life cycle of the fish (Rosenfeld, 2003; Jonsson \& Jonsson, 2011) and may function as a bottleneck for the entire population in terms of (a) quantity (e.g. Armstrong et al., 2003; Bjorn \& Reiser, 1991; Barlaup et al. 2008) or (b) quality (e.g. Gregory \& Bisson, 1997, Pulg et al., 2013). Lack of spawning habitats in salmonid rivers may be the 
consequence of (i) river training works (e.g. Gibson et al., 2005) or (ii) sediment disturbances at the reach (Wheaton et al., 2010) or the catchment scale (Buffington et al., 2004), leading to deficits of spawning gravel without the opportunity for self-forming renewal (Sawyer et al., 2010; Hauer et al., 2011). Especially in the mid to long term, the disturbance/ interruption of the sediment continuum results in a sustainable degradation (Kondolf, 1997) or high sensitivity of spawning sites against anthropogenic measures, especially if the sediment continuum is naturally disturbed or interrupted (e.g. by lakes) (Hauer et al., 2015).

One driver beside gravel movement/armoring by floods for the degradation of spawning habitats are often fines infiltrating the gravel matrix and clogging pore space (Soulsby et al., 2001; Pulg et al., 2013). Fine sediment infiltration yields reduced oxygen supply at spawning sites (Lisle \& Lewis, 1992), resulting in a range of physiological impacts including reduction in weight and length, morphological adaptations (extended yolk sac), and hypoxia (Kemp et al., 2011). In Western Norway, however, the sediment supply in non-glacial river catchments is comparatively low (including fines) with usually $<15 \mathrm{t} \mathrm{km}^{-2}$ per year (Bogen, 2015) compared to for e.g. 250-1000 $\mathrm{t} \mathrm{km}^{-2}$ annually at the U.S. West Coast mountain ranges (Walling \& Webb, 1996). Due to thin soil cover (Rosenqvist, 1978) and low percentage of agricultural land use $(<3 \%$; Olsson et al., 2000), the deposition of fines in rivers (diameter $<1 \mathrm{~mm}$ ) is therefore often considered of minor importance for spawning success, even in terms of very low flow velocities (Barlaup et al., 2008). The challenging components for the occurrence of salmonid spawning sites in Western Norway are therefore rather high-gradient rivers and erosion of gravel under supply-limited geological conditions (Hauer et al., 2013, 2015). Moreover, river regulation has partly reduced gravel supply by reducing flow dynamics, riverbed and bank stabilization and dams (Barlaup et al., 2008; Forseth et al., 2017).

In the rivers of Western Norway, there are only five native fish species: Atlantic salmon (Salmo salar Linnaeus, 1758), brown trout (Salmo trutta trutta Linnaeus, 1758), arctic char [Salvelinus alpinus (Linnaeus, 1758)], three-spined stickleback (Gasterosteus aculeatus Linnaeus, 1758) and eel [Anguilla Anguilla (Linnaeus, 1758)]. Those fish were able to populate the rivers from the sea after melting of the ice which covered the entire Norwegian coast during the last ice age (Huitfeld-Kaas, 1918). At the national scale, the populations of Atlantic salmon and sea trout are particularly important. Many populations are endangered due to (i) uncontrolled spread out of sea lice by salmon farming in open net pens and farm escapees (ii) hydropower impacts, like hydropeaking (e.g.) or water abstraction (Thorstad et al., 2008) or (iii) due to river training measures, like flood protection (Krkošek et al., 2007; Thorstad et al., 2008; Costello, 2009; Sauterleute et al., 2016; Forseth et al., 2017)). River regulation is recognized as a crucial factor for the degradation of spawning sites, leading to possible bottleneck conditions for entire populations in specific catchments (e.g. Hauer et al., 2015).

Spawning of Atlantic salmon and sea trout have been well studied (e.g. see review in Klemetsen et al., 2003). The foci include habitat use (Armstrong et al., 2003) and sedimentary characteristics of spawning sites (Moir et al., 1998) including analysis of intergravel flow (Louhi et al., 2008). Moreover, spawning migration (Thorstad et al., 2008) and the time of spawning (Heggberget, 1988) were investigated as well as the energy costs (Jonsson et al., 1991) and reproduction strategies (Fleming, 1996). However, besides knowledge of spawning behaviour and physical characteristics, river and fish management needs predictive tools to maintain and restore spawning grounds; otherwise, the measures risk short endurance (Barlaup et al., 2008; Hauer et al., 2013).

In contrast to two-dimensional hydrodynamic-numerical models, only limited studies used multidimensional sediment transport models for calculating sediment transport dynamics at salmonid spawning site (e.g. Gaeuman et al., 2017). Thus, there is an evident lack of validation and comparable data about the predictive quality of hydrodynamic-numerical sediment transport models in terms of spawning restoration. Common and frequently applied predictive tools in hydraulic engineering are hydrodynamicnumerical models (Lane, 1998; Nicholas \& Walling, 1997) which are also used for spawning habitat restoration (Ghanem et al., 1996; Pasternack et al., 2004; Gard, 2006; Hauer et al., 2011, 2015). Hydrodynamic-numerical models offer different dimensions of calculating flow velocities with different opportunities for investigating spawning habitats. Simple onedimensional (step backwater) models have been applied for cross-sectional-based analysis of the river 
(e.g. variance in width and depth) at characteristic flow stages (Brunner, 1998; Hauer et al., 2015), including flood dynamics (e.g. Hauer \& Habersack, 2009). More complex two-dimensional models have been used for modelling habitat suitability (Leclerc et al., 1995) or evaluation of restoration designs (Brown \& Pasternack, 2009). Three-dimensional modelling including near-bottom flow velocities are rare (Tonina \& Buffington, 2007), but can highlight important hydraulic boundaries for inter-gravel flow (Obruca \& Hauer, 2017).

For spawning habitat restoration, the following methods are recommended: (i) gravel augmentation (also to promote sediment continuity), (ii) hydraulic adjustments and (iii) mechanical treatment (Wilcock et al., 1996; Wheaton et al., 2004; Brown, \& Pasternack, 2014; Gaeuman, 2014; Gaeuman et al., 2017). In Western Norway, the restoration of degraded and partly lost spawning habitats of Atlantic salmon and sea trout was mainly achieved by artificial gravel dumping (e.g., Barlaup et al., 2008), a measure not only frequently applied below dams (Brown \& Pasternack, 2008), but also for the restoration of fluvial processes (Fjeldstad et al., 2012). Other restoration techniques include hydraulic structure placement (e.g., single boulders or groynes), mainly to create suitable water depths and flow velocities combined with specific sediment sorting, or an "artificial enhancement" of existing spawning gravels by periodic turnovers of spawning substrate to reduce the amount of aggregated fine sediments at spawning grounds (Pulg et al., 2013) .

Although there are some monitoring studies for gravel augmentation (compare to Merz \& Ochikubo, 2005; Zeug et al., 2014; Sellheim et al., 2015), the monitoring of evolution of gravel injection is lacking (except for the Wheaton et al., 2010). This shortcoming in combination with the lack of validation of sediment transport models (e.g. Hauer et al., 2011) and the quality of their performance in the prediction of sediment dynamics at spawning sites highlighted that there are obvious problems in the management of reproduction sites, which needs to be addressed. For the presented study, gravel augmentation in the river Aurlandselva was selected as a model system to address these shortcomings.

The research questions of the presented study were: (1) How stable were the artificial gravel spawning placements? and (2) are they still suitable after overforming and re-distribution by floods of different sizes? The hypothesis for these research questions was that the success of spawning gravel supplementation depends on local river morphology and hydraulics and that state of the art management tools for prediction of bed stability are able to reproduce the derived changes observed by field studies.

Various sites in Aurlandselva, Norway have been restored for spawning by artificial gravel placement in the period 2010-2013. In 2015, all sites were monitored concerning their possible changes based on Digital GPS - measurement and volumetric sediment sampling for the determination of (i) the quality of spawning gravel, (ii) grain size distributions and (iii) the thickness of gravel layers. A two-dimensional depth-averaged sediment transport model was applied to calculate flood impacts and the possible distribution of the spawning gravel in the river.

\section{Study reach}

The study area is located in the western part of Norway, in the county of Sogn-og-Fjordane (municipality of Aurland). The $802 \mathrm{~km}^{2}$ large catchment area of the Aurland river (Aurlandselva) is largely an alpine plateau with numerous lakes, ponds and waterways (Faugli, 2008). Around 90\% of the total catchment area is above an altitude of $1000 \mathrm{~m}$ a.s.l. (Tvede, 2008). The $6.8 \mathrm{~km}$ long Aurlandselva is the lower part of the water body. The river discharges from the northwestern side of the lake (N60 $52^{\prime} 32^{\prime \prime} \mathrm{E} 7^{\circ} 15^{\prime}$ $\left.52^{\prime \prime}\right)$ and drains into the Aurlandsfjord at Aurlandsvangen $\left(\mathrm{N} 60^{\circ} 54^{\prime} 18^{\prime \prime} \mathrm{E}^{\circ} 11^{\prime} 00^{\prime \prime}\right)$, a southeastern branch of the Sognefjord (Faugli, 2008). In the section between lake and mouth of the river, the valley width increases and provides some area for agricultural land use, but its overall percentage of the drainage is low ( $<$ 1\%; Faugli, 2008). The river stretch has an average bedslope of 0.0069 , a mean depth of $0.66(\mathrm{~m})$, and mean width of $23.4(\mathrm{~m})$ during low flow conditions $\left(3 \mathrm{~m}^{3} \mathrm{~s}^{-1}\right)$. In Fig. 1, the catchment and the investigated reach of the Aurlandseleva are presented. Data regarding the hydrology are described in Table 1 and are generated by the database of the Norwegian water authorities (NVE, http://nevina.nve.no/ accessed in September 2018).

Between 1969 and 1988, a total number of five hydropower plants (HPs) were constructed in the 


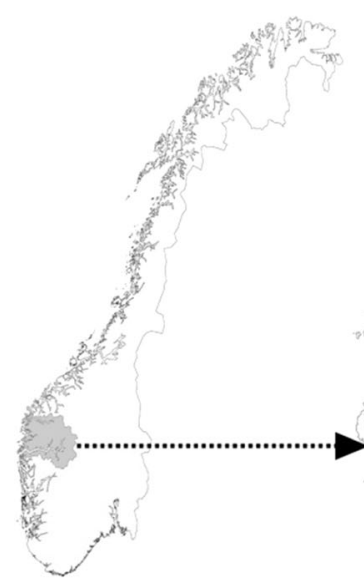

Norway

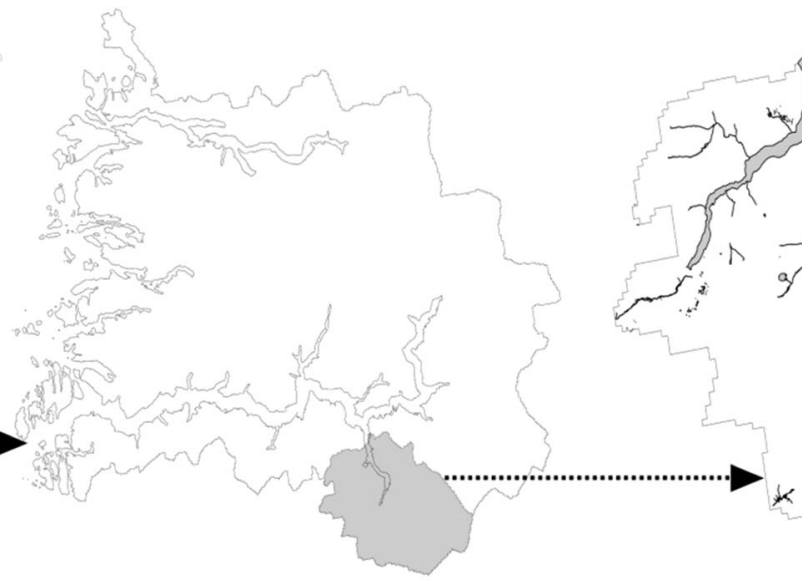

Sogn og Fjordane

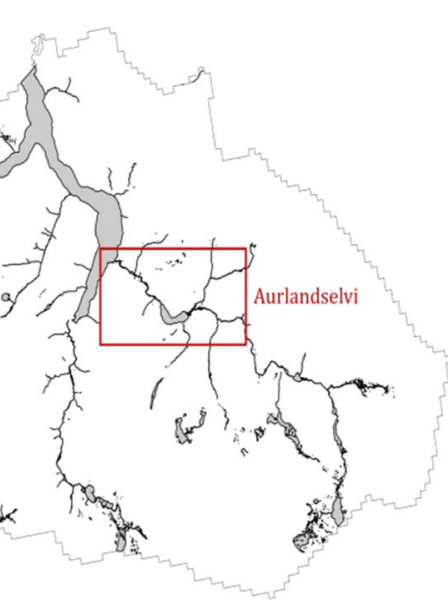

Aurland kommune

Fig. 1 Study reach of the Aurlandselva located in the county of Sogn og Fjordane / Norway

Table 1 Hydrological characteristics of the investigated Aurlandselva/Norway for two periods (i) unregulated (ii) after hydropower implementation

\begin{tabular}{|c|c|c|c|c|c|}
\hline \multirow{2}{*}{$\begin{array}{l}\text { Time } \\
\text { period }\end{array}$} & \multirow{2}{*}{$\begin{array}{l}\text { Low flow } \\
\left(\mathrm{m}^{3} \mathrm{~s}^{-1}\right)\end{array}$} & \multirow{2}{*}{$\begin{array}{l}\text { Mean annual flow } \\
\left(\mathrm{m}^{3} \mathrm{~s}^{-1}\right)\end{array}$} & \multirow{2}{*}{$\begin{array}{l}\text { Mean annual flood } \\
\left(\mathrm{m}^{3} \mathrm{~s}^{-1}\right)\end{array}$} & \multicolumn{2}{|l|}{ Residual flow $\left(\mathrm{m}^{3} \mathrm{~s}^{-1}\right)$} \\
\hline & & & & $\begin{array}{l}\text { (June 16-September } \\
\text { 13) }\end{array}$ & $\begin{array}{l}\text { (September 14-June } \\
15)\end{array}$ \\
\hline 1909-1973 & 1.92 & 37.11 & 290.96 & - & - \\
\hline 1990-2014 & 2.81 & 16.98 & 92.23 & $20.00-30.00$ & 3.00 \\
\hline
\end{tabular}

watershed of the Aurlandselva. Water is collected and stored in reservoirs on the mountains and used for power production on demand. Based on the construction of power plants and their respective reservoirs, the hydrology in the catchment and discharge regime of the Aurlands river, respectively, have been changed (Table 1). The changes in the discharge regime of the Aurlandselva consist mainly of a more even discharge distribution, with lower maximum peaks and lower spring floods as well as a little increase of the winter minimum due to the residual flow schemes (from 1.8 to $3 \mathrm{~m}^{3} \mathrm{~s}^{-1}$ ) (database: E-Co Energi) (compare to Fig. 2). After regulation, both Atlantic salmon and sea trout stocks declined (Jensen et al., 2008; Pulg et al., 2013b). Moreover, these changes have led to a reduced supply with spawning gravel and less spawning habitat due to less bank erosion in those parts, which are running through glacial tills and terraces (Pulg et al., 2013b). Another significant change was the reduction in the summer water temperature in Aurlandselva (11 degrees daily average summer before, 9 degrees after) due to direct transfer of high-altitude mountain water and reservoir water through the penstock tunnels. Other regulation factors reduced fish habitat, especially severing side channels and erosion protection on the bank reducing input of glaciofluvial sediments containing sand, gravel and pebbles (Pulg et al., 2013b). In the concession for Aurland HP regulation, there is an obligation for the HP company to stock the river with 40,000 salmon smolts and 10,000 sea trout smolts. The effect of this stocking program was not satisfying, and from 2009 different physical mitigation measures and the stocking of salmon eggs have been prioritized as mitigation measures. The artificial gravel placement is one of the core issues of the mitigation program. 


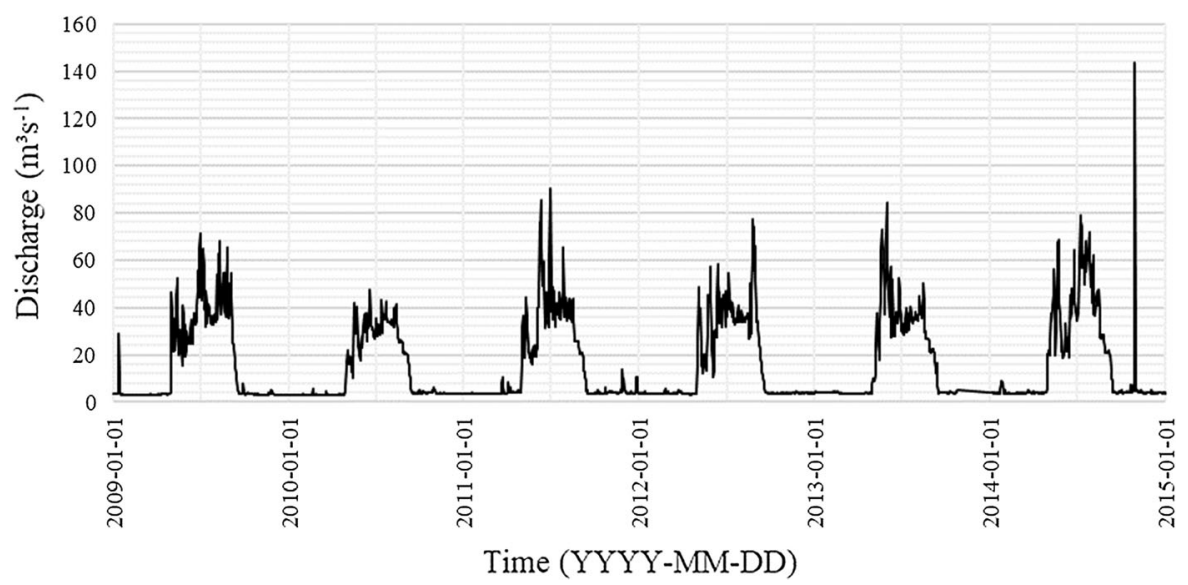

Fig. 2 Continuous recorded data during the monitoring period of artificial gravel placement in the Aurlandselva (2010-2015) (Note short flood peak in 2014)

\section{Methods}

The research questions and the hypothesis were tested based on a combination of both (i) field investigations and (ii) numerical modelling. Field studies included the mapping of spawning sites with grain size analysis and the documentation of possible changes over time (research question 1). Moreover, modelling was applied to study possible interaction of river bathymetry and sediment dynamics as well as the predictability of two-dimensional depth-averaged sediment transport modelling to estimate the life span and morphodynamics of reproduction sites of sea trout and Atlantic Salmon (research question 2).

\section{Mapping of spawning sites}

Fieldwork was conducted in 2015 from March 23rd to March 25th, and in the period 23rd until the 29th of April during low flow conditions and immediately after gravel placement (2010-2013). The mapping of spawning sites was done downstream of Lake Vassbygdvatnet (Fig. 1), in chronological order following downstream distance from the lake outlet. Spawning habitats were measured by a Digital Global Positioning System (Trimble T3; horizontal precision $2 \mathrm{~cm} /$ vertical precision $5 \mathrm{~cm}$ ). The edge of spawning sites was determined by accurate point sampling of the area ( $n>10)$ covered by spawning gravel, allowing the drawing of polygons and the quantification of spatial extent for each of the sites. Two lines have been mapped at the reproduction sites: (i) red area $=$ distribution of spawning gravel after implementation (initial phase) (gravel layer depth $=5-30 \mathrm{~cm}$ ) (Fig. 3) and (ii) yellow area = reshaped, partially scoured and re-deposition sites (evolution phase) with only a limited suitability for spawning (gravel layer depth $<$ $10 \mathrm{~cm}$ ) (Fig. 3). For quantification of changes over time the mapped areas of 2015 were compared with the maps after implementation (initial phase).

Local substrate sampling spawning sites

Artificially deposited spawning gravel was sampled at the dropped sites to determine the actual grain size distribution in 2015 for both the following: (i) the comparison between spawning sites for the discussion about the quality of substrate for reproduction and (ii) as an indication for possible changes in the substrate composition. Volumetric sediment samples were taken at each restored site $(n=12)$ during low flow conditions from the surface and subsurface layer in April 2015 and immediately after gravel placement out of $0-15 \mathrm{~cm}$ depth by shovelling the substrate directly into a submerged sampling net of $150 \mu \mathrm{m}$ according to Barlaup et al. (2008). Samples were dry sieved using $0.125,0.25,0.5,1,2,4,8,16,32,64 \mathrm{~mm}$ sieves. Percentage fines were defined as the proportion of sediment finer than $1 \mathrm{~mm}$ and the average grain size $\mathrm{D}_{50}$ was calculated after Rubin \& Glimsäter (1996). Based on the sediment samples, the critical shear stress for the initiation of motion was calculated based on Meyer-Peter \& Müller (1948). The formula was selected as the validity of the formula according to 


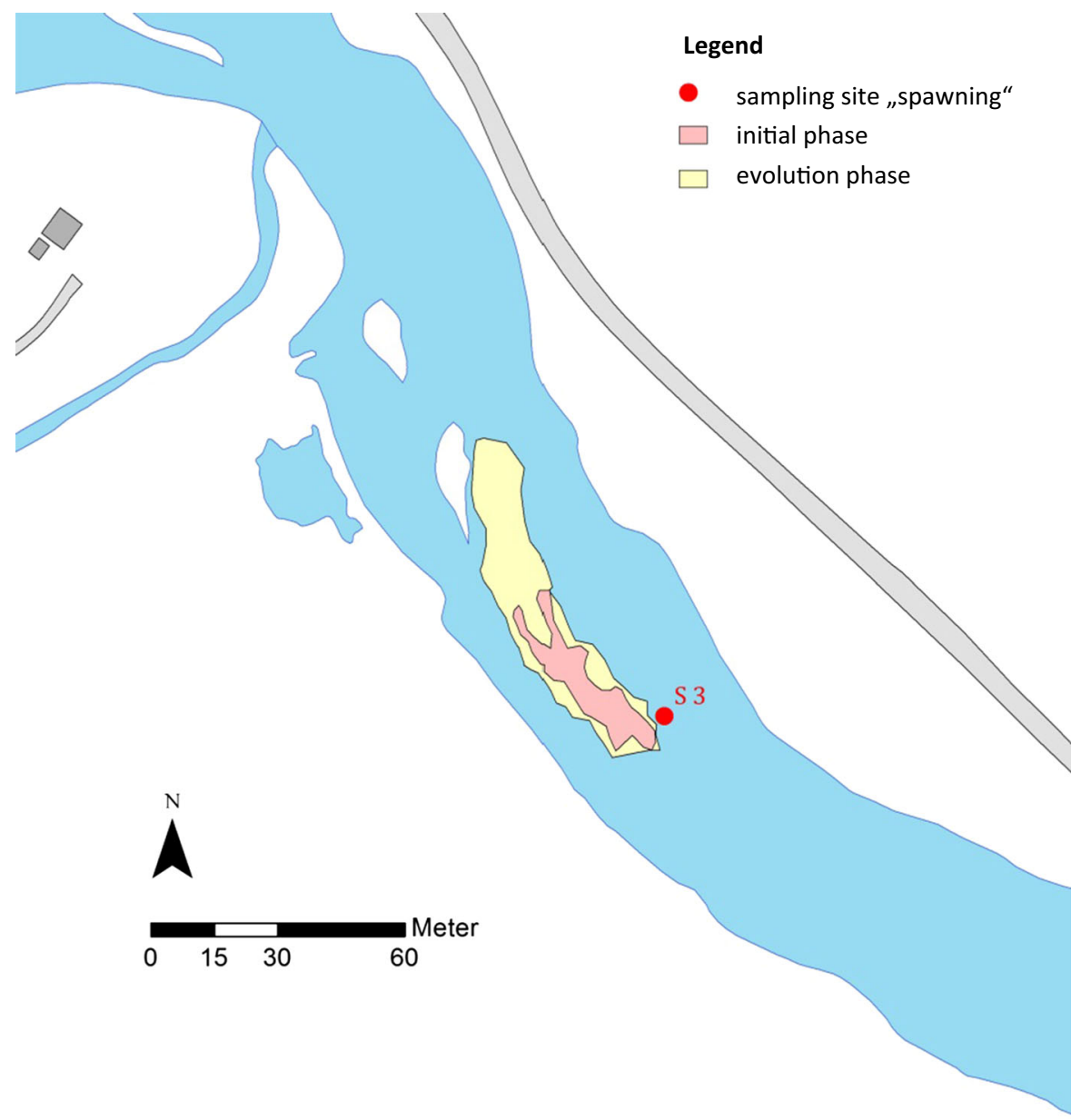

Fig. 3 Example of GIS method for mapping spawning sites in the Aurlandselva (spawning site S3); red area = distribution of spawning gravel after implementation (gravel layer depth = $5-30 \mathrm{~cm}$ ) (initital phase) and yellow area $=$ overformed,

slope $(0.0004<S<0.02)$ that fits to the given situation at the Aurlandselva $(S \sim 0.01)$. The MPM-equation calculates the critical shear stress $\left(\tau_{c r}\right)$ for specific sediment size classes by taking the mean diameter $\left(d_{\mathrm{m}}\right)$ into account.

$\tau_{\mathrm{cr}}=0.047 \cdot\left(\rho_{\mathrm{F}}-\rho_{\mathrm{W}}\right) \cdot g \cdot d_{\mathrm{m}}$,

where $\rho_{\mathrm{F}}=$ sediment density $\left(2665 \mathrm{kgm}^{-3}\right), \rho_{\mathrm{W}}=$ water density $\left(1000 \mathrm{kgm}^{-3}\right), d_{\mathrm{m}}=$ average diameter of sediment (m) and $g=$ gravitational acceleration $\left(9.81 \mathrm{~ms}^{-2}\right)$. partially scoured and re-deposition sites (evolution phase) with only a limited suitability for spawning (gravel layer depth < $10 \mathrm{~cm}$ )

Reach scale substrate sampling $d_{90}$

In addition to substrate sampling at the spawning sites $(n=12)$, the entire substrate characteristics of the studied river were evaluated. Here, the sampling focused on the characterisation of micro-topographical features of the streambed, reflected by the coarsest sediments in a river reach influencing local hydraulics. Thus, the second sediment sampling campaign was focusing on the reach scale characteristics of the $d_{90}$ distribution. Here, a novel sampling approach according to Hauer \& Pulg (2018) was applied, which is a method based on an adjusted Wolman count (Wolman, 1954). The sediment sampling focused on the largest grains $\left(d_{90}\right)$ and was performed for minimum 50 
sediment patches in maximum $500 \mathrm{~m}$ long reaches during wadable conditions in the Aurlandselva. The largest grain per patch was selected as this measure can be more easily determined in the field than volume-based grain size characteristics such as $d_{84}$ or $d_{50}$ which demand that standardized sediment volumes need to be excavated and sampled (compare to 3.2). The sampling consisted of measuring the $b$-axis of the largest particle for a representative $4 \mathrm{~m}^{2}$ sediment patch of the reach (sampling area: $2 \mathrm{~m} \times 2 \mathrm{~m}$ ) using a random walk approach (Hauer \& Pulg, 2018) including the wetted area during high flow. The step spacing of the walk was adjusted to the size of the area to be covered for the size of the particles (e.g., Yuzyk, 1986) in the investigated rivers.

Determination of bed coarseness in relation to introduced gravel substrate

The rivers in Western Norway contain partially very coarse river substrate due to the glacial history (compare to Hauer \& Pulg, 2018), which deviate significantly in size to the gravel to small cobble fractions which are artificially introduced for spawning habitat restoration. To consider this variability of given sedimentological conditions of substrate injection, we calculated a bed coarseness ratio between average gravel diameter of the deposited spawning gravel $\left(d_{50}\right)$ and the $d_{90}$ of the river substrate sampled by the reach scale method according to Hauer \& Pulg (2018). We suggest the ratio as an index for characterization of artificial spawning gravel placements, (Eq. 5) (see figure supplementing material). This parameter, as non-dimensional relationship, reflects the difference of the introduced gravel to the microtopographical roughness of the riverbed framework. The derived bed coarseness ratio (BCR) has a strong implication on near-bottom flow characteristics like flow velocity or turbulence like it has been already figured out in a variety of studies (Brayshaw et al., 1983; Naden \& Brayshaw, 1987; Powell, 2014; MacKenzie et al., 2018).

$\mathrm{BCR}=d_{50}$ gravel substrate $/ d_{90}$ bed surface
Hydrodynamic-numerical sediment transport modelling

A two-dimensional depth-averaged hydrodynamicnumerical $(\mathrm{HN})$ model was applied for hydraulic simulations and hydro-morphological analyses at spawning sites. The Hydro_AS-2d software was used for this form of analysis. The model, developed by Nujic (1999), enables modelling on an unstructured grid using the SMS software as a pre- and postprocessing tool, based on a finite volume approach. The hydrodynamic-numerical model was additionally extended by the sediment transport module (Hydro_GS) which allows sediment transport modelling and consideration of morphodynamic processes to be simulated on a two-dimensional plane (Nujic, 2008). Due to the limiting single grain size approach by using $\mathrm{d}_{\mathrm{m}}$ (mean diameter), several processes related to sediment sorting (e.g. downstream fining at bars), however, cannot be addressed by the applied version of Hydro_GS. Nevertheless, based on definitions of unerodible areas within the modelling grid, certain morphological/sedimentological characteristics (e.g. inerodible armour layer for a specific discharge) might be considered. Changes in bed level due to sediment transport are calculated by Hydro_GS according to the Exner equation (Eq. 3).

$$
\begin{aligned}
& \left(1-n_{\mathrm{p}}\right) \rho_{\mathrm{s}} \frac{\delta z}{\delta t}+\operatorname{div} \overrightarrow{g_{\mathrm{s}}}=s, \quad \overrightarrow{g_{\mathrm{s}}}=\sum \overrightarrow{g_{\mathrm{si}}}, \\
& s=\sum s_{\mathrm{i}}
\end{aligned}
$$

where $\rho_{\mathrm{s}}=$ density of sediments $\left(2650 \mathrm{~kg} \mathrm{~m}^{-3}\right)$, $n_{\mathrm{p}}=$ porosity of the river bed $(0.37), g_{\mathrm{s}}=$ vector of bed load transport, $s=$ erosion/deposition term of suspended sediments.

For sediment transport modelling, the bed load was calculated based on the extended Meyer-Peter and Müller formula (1948) (Eq. 4).

$$
\begin{aligned}
& g_{\mathrm{s}}=\phi \sqrt{\left(\rho_{\mathrm{r}}-1\right) g d_{\mathrm{m}}^{3 / 2}}, \\
& \phi=c_{\mathrm{MP}}\left(\theta^{\prime}-\theta_{\mathrm{cr}}\right)^{3 / 2} \quad \theta^{\prime}=\mu \frac{h J}{\left(\rho_{\mathrm{r}}-1\right) d_{\mathrm{m}}} \\
& \mu=\left(\frac{k_{\mathrm{St}}}{k_{\mathrm{St}}^{\prime}}\right)^{3 / 2},
\end{aligned}
$$

where $h=$ water depth (m), $g=$ acceleration due to gravity $\left(9.81 \mathrm{~ms}^{-2}\right), d_{\mathrm{m}}=$ mean diameter $(\mathrm{m}), \rho_{\mathrm{r}}=$ $\rho_{\mathrm{s}} / \rho_{\mathrm{w}}$ relative density $\left(\rho_{\mathrm{w}}=\right.$ density of water) $(-)$, 
$\mu=$ ripple coefficient $(-), k_{\mathrm{st}}=$ roughness coefficient (Strickler), $\quad k_{\mathrm{st}}^{\prime}=$ grain roughness, $\theta_{\mathrm{cr}}=$ critical Shields parameter $(0.03), J=$ frictional slope $(-)$ and $c_{\mathrm{MP}}=$ pre-factor in MPM-Eq. (7.3).

The applied model (Hydro_GS) determines the frictional slope according to the Manning-Strickler equation (Eq. 5).

$J=\frac{v^{2}}{k_{\mathrm{St}}^{2} h^{4 / 3}}$,

where $v=$ depth-averaged flow velocity $\left(\mathrm{ms}^{-1}\right)$ and $h=$ water depth (m).

Steady state discharge simulations were used to model sediment transport and to analyse deposition rates at the artificial and natural spawning sites $(n=12)$ of anadromous brown trout and Atlantic Salmon at the Aurlandselva, taking representative grain sizes into account. Roughness coefficients (Mannings $n$ ) were calibrated under low flow conditions $\left(3.88 \mathrm{~m}^{3} \mathrm{~s}^{-1}\right)$, validated in relation to the Hauer et al. (2015) study with an overall roughness (grain, form roughness) of $n=0.91$ and were modified due to rising stages (e.g. hundred years flood, $n=0.056$ ). Hydrological scenarios are based on the recorded discharge data of the monitoring period (Fig. 2). For the two-dimensional depth-averaged sediment transport model, only the highest discharge of 2014 with $143.6 \mathrm{~m}^{3} \mathrm{~s}^{-1}$ (Fig. 2) was used as it was assumed that this flow rate contains the maximum forces (e.g. bottom shear stress) responsible for maximum reshaping of the investigated spawning sites.

\section{Biological monitoring}

Six of the spawning areas spread from the lake outlet to the mouth of the Aurlandselva were monitored biologically in the period 2010-2015. Each year, it was checked if fish had spawned by searching for spawning redds and eggs following the method of Barlaup et al. (2008). The sites were searched for typical spawning redds, a characteristic pit in the gravel and a tail of gravel directly downstream. In March, when eggs were eyed and tolerated movement, the redds were researched under water by carefully removing gravel with a shovel until potential eggs were found. Spawning could thus be verified.

Electrofishing was conducted directly at the spawning sites to register potential changes in the reproduction of the fish. A one-pass electro fishing method was used as described by Hedger et al. (2018) and Pulg et al. (2019). An area of 50-100 $\mathrm{m}^{2}$ at each test site was sampled each October by using a Terik backpack electrofishing device at an impulsed current $(1400 \mathrm{~V}, 70 \mathrm{HZ})$. The temperature during fishing was $7-9.5^{\circ} \mathrm{C}$ and conductivity was $10-20 \mu \mathrm{S} \mathrm{cm}{ }^{-1}$. Results are presented as densities of individuals per species per $100 \mathrm{~m}^{2}$. It is distinguished between fry (young of the year, 3-7 cm, indicating last year's reproduction success) and parr (older juveniles, $7.1-15 \mathrm{~cm}$ ) indicating reproduction of 2 and 3 years before.

\section{Results}

The results are presented under the line of three topics: (i) the mapping of spawning sites including quantification of erosion rates as well as prediction of life time characteristics (research question 1), (ii) the analysis of the grain size distribution at spawning sites and (iii) the prediction of morphodynamics based on the twodimensional depth-averaged numerical model (research question 2). In Fig. 2, the hydrological data for the monitoring period (2010-2015) are presented, which are the basics for interpretation of both the measuring of erosion and re-distribution of spawning gravel as well as boundary conditions for hydrodynamic-numerical modelling.

Mapping of spawning sites

The results of the GPS survey of natural $(n=2)$ and artificial $(n=10)$ spawning habitats including (i) various sub-areas, (ii) the implementation date, (iii) the cubic volume and (iv) the spatial extent after overforming of the respective gravel addition can be seen in Tables 2 and 3. The gravel areas after placement (initial phase) had a bulk volume of approximately $4 \mathrm{~m}^{3}-32 \mathrm{~m}^{3}$ with an extension of the individual surfaces of artificial spawning sites of 18 sqm-144 sqm. The range of layer thicknesses of gravel pads ranged from $5 \mathrm{~cm}-30 \mathrm{~cm}$ after construction. In Table 3, the results of the sampling in 2015 are presented including percentage of gravel at spawning sites and the degree of erosion (evolution phase). The data reveal that a high variability in erosion rates exists. The gravel dumping of 2013 exhibited erosion 
Table 2 Description of investigated (i) natural and (ii) artificially placed spawning sites including year of implementation, grain size characteristics and degree of erosion

\begin{tabular}{|c|c|c|c|c|c|c|c|}
\hline \multicolumn{8}{|c|}{ Spawning habitats } \\
\hline Reach & Habitat & Category & Year & $d_{\mathrm{m}}(\mathrm{mm})$ & Percentage fines $(\%)$ & Percentage gravel (\%) & Degree of erosion $(\%)$ \\
\hline \multirow[t]{3}{*}{ A1 } & S1 & Deposited & 2010 & 20.9 & - & 100 & 33 \\
\hline & S2 & Natural & - & 68.3 & 6 & 42 & - \\
\hline & S3 & Deposited & 2010 & 24.1 & - & 100 & 33 \\
\hline \multirow[t]{2}{*}{ A2 } & S4 & Deposited & 2010 & 23.8 & 0 & 96 & 52 \\
\hline & S5 & Deposited & 2013 & 82.0 & 2 & 46 & 95 \\
\hline \multirow[t]{3}{*}{ A3 } & S6 & Deposited & 2013 & 77.5 & - & 21 & 95 \\
\hline & S7 & Deposited & 2010 & 28.5 & - & 100 & 34 \\
\hline & S8 & Deposited & 2010 & 32.3 & 2 & 42 & 75 \\
\hline \multirow[t]{4}{*}{ A4 } & S9 & Natural & - & 31.5 & 6 & 59 & - \\
\hline & S10 & Deposited & 2011 & 34.2 & 6 & 57 & 32 \\
\hline & S11 & Deposited & 2010 & 57.4 & 4 & 41 & 40 \\
\hline & $\mathrm{S} 12$ & Deposited & 2013 & 7.8 & 8 & 68 & 92 \\
\hline
\end{tabular}

rates of almost $95 \%$. In contrast, the artificial spawning sites that have been implemented in 2010 and 2011 contained erosion rates only of $33-75 \%$ (mean: 42.7\%). These findings are underlined by the data in Fig. 4 and Table 2, where the changes in deposited volumes are presented, showing especially high losses and re-distribution of gravel for S6 and S12 implemented in 2013.

This evaluation of the evolution phase allowed further predictions of the life span according to the erosion rates of the past hydrological events (compare to Fig. 2). Based on these calculations, a maximum life span of 15 years is calculated for the artificial gravel dumping sites, with an overall average of 9.2 years. With regard to the evolution phase of spawning habitat development, it can be seen that in the period between gravel addition (in 2010, 2011 and 2013) and the actual condition survey (2015), in six out of 10 spawning habitats, the total usable spawning area (S1, S4, S5, S6, S8 and S12) was reduced. In the remaining four habitats, however, aggregation and accumulation of the gravel material led to an increase in total area (S3, S7, S10 and S11) (Table 3). New spawning gravel areas, which might have formed below the addition sites through erosion and deposition processes, are not included in this study.
Substrate sampling at spawning sites

The result of sieving of the artificially deposited gravel are presented in Fig. 5. When dumped in 2010, the gravel was comprised of $1.4 \%$ fines with an average grain $\left(D_{50}\right)$ size of $33.4 \mathrm{~mm}$ (test sites $1,3,7,8,10$ and 11). In 2015 , the percentage fines was $1.2 \%$ and the $\mathrm{D}_{50}$ was $31.2 \mathrm{~mm}$. Material was mainly composed of coarse gravel (>16 mm, approximately 59\%). The remaining components are distributed among the classes of mean gravel (approximately 30\%) and fine gravel (approximately 1\%). No accumulation of fines was observed in the 5-year period. Rather, sediment transport leads to partial coarsening of the substrate e.g at the test sites (e.g. S5, S6). However, no correlation $\left(R^{2}=0.2\right)$ was given for all tested sites by comparing grain size distribution and erosional rate (Table 2).

Reach scale substrate sampling $d_{90}$

The results of the coarsest sampled grains to determine the surface layer stability and micro-topographical roughness exhibit a certain decrease along the study reach. The mean $d_{90}$ for the first five sampled reaches vary between 57.2 and $64.8 \mathrm{~cm}$ (Fig. 6) with large variations due to partially non-fluvial sediments (see supplementing material). For the reaches 6 to 14, mean $d_{90}$ was calculated with $30.4-49.8 \mathrm{~cm}$ (Fig. 6). The 
Table 3 Development of the deposited volumes of investigated spawning sites including the numbers about the total volume after deposition and the remaining volume of gravel in 2015 as well as the predicted life time depending on the degree of erosion

\begin{tabular}{|c|c|c|c|c|c|c|c|c|c|c|}
\hline \multicolumn{11}{|c|}{ Development of deposited volumes } \\
\hline \multirow[t]{2}{*}{ Habitat } & \multirow[t]{2}{*}{ Sub. } & \multirow[t]{2}{*}{ Deposition } & \multicolumn{2}{|c|}{ After deposition } & \multicolumn{2}{|l|}{2015} & \multicolumn{4}{|c|}{ Life time } \\
\hline & & & $\begin{array}{l}\text { Volume } \\
\text { total }\left(\mathrm{m}^{3}\right)\end{array}$ & $\begin{array}{l}\text { Volume } \\
\text { gravel } \\
\left(\mathrm{m}^{3}\right)\end{array}$ & $\begin{array}{l}\text { Volume } \\
\text { total }\left(\mathrm{m}^{3}\right)\end{array}$ & $\begin{array}{l}\text { Volume } \\
\text { gravel } \\
\left(\mathrm{m}^{3}\right)\end{array}$ & $\begin{array}{l}\text { Time } \\
\text { period } \\
\text { (years) }\end{array}$ & $\begin{array}{l}\text { Volume } \\
\text { reduct. } \\
(\%)\end{array}$ & $\begin{array}{l}\text { LT total } \\
\text { (years) }\end{array}$ & $\begin{array}{l}\text { LT since } \\
2015 \\
\text { (years) }\end{array}$ \\
\hline $\mathrm{S} 1$ & $\_1$ & Apr-2010 & 8 & 8.0 & 5.4 & 5.4 & 5.0 & 33 & 15.4 & 10.4 \\
\hline $\mathrm{S} 2$ & \multicolumn{2}{|l|}{-1} & \multicolumn{2}{|c|}{ Nat. spawn. site } & \multicolumn{2}{|c|}{ Nat. spawn. site } & \multicolumn{4}{|c|}{ Nat. spawning site } \\
\hline \multirow[t]{2}{*}{$\mathrm{S} 3$} & _1 & Apr-2010 & 32.0 & 16.0 & 21.6 & 7.6 & 5.0 & 33 & 15.3 & 10.3 \\
\hline & $\_^{2}$ & Apr-2010 & & 16.0 & & 14.0 & & & & \\
\hline \multirow[t]{6}{*}{$\mathrm{S} 4$} & -1 & Apr-2010 & 32.0 & 8.0 & 15.5 & 12.9 & 5.0 & 52 & 9.7 & 4.7 \\
\hline & $\_^{2}$ & Apr-2010 & & 8.0 & & 1.9 & & & & \\
\hline & -3 & Apr-2010 & & 4.0 & & 0.7 & & & & \\
\hline & -4 & Apr-2010 & & 4.0 & & - & & & & \\
\hline & $\_5$ & Apr-2010 & & 4.0 & & - & & & & \\
\hline & _6 & Apr-2010 & & 4.0 & & - & & & & \\
\hline S5 & _1 & Sep-2013 & 8.0 & 8.0 & 0.4 & 0.4 & 1.5 & 95 & 1.6 & 0.1 \\
\hline \multirow[t]{4}{*}{ S6 } & -1 & Sep-2013 & 32.0 & 8.0 & 1.5 & 0.5 & 1.5 & 95 & 1.6 & 0.1 \\
\hline & 2 & Sep-2013 & & 8.0 & & 0.5 & & & & \\
\hline & -3 & Sep-2013 & & 8.0 & & 0.5 & & & & \\
\hline & -4 & Sep-2013 & & 8.0 & & - & & & & \\
\hline \multirow[t]{2}{*}{ S7 } & -1 & Apr-2010 & 32.0 & 16.0 & 21 & 9.8 & 5.0 & 34 & 14.5 & 9.5 \\
\hline & -2 & Apr-2010 & & 16.0 & & 11.2 & & & & \\
\hline S8 & $\_1$ & Apr-2010 & 8.0 & 8.0 & 2 & 2.0 & 5.0 & 75 & 6.7 & 1.7 \\
\hline S9 & \multicolumn{2}{|l|}{-1} & \multicolumn{2}{|c|}{ Nat. spawn. site } & \multicolumn{2}{|c|}{ Nat. spawn. site } & \multicolumn{4}{|c|}{ Nat. spawning site } \\
\hline \multirow[t]{3}{*}{$\mathrm{S} 10$} & $\_1$ & Apr-2010 & 48.0 & 8.0 & 32.6 & 1.8 & 3.5 & 32 & 10.9 & 7.4 \\
\hline & ${ }_{2} 2$ & Sep-2011 & & 18.0 & & 16.3 & & & & \\
\hline & -3 & Sep-2011 & & 22.0 & & 14.6 & & & & \\
\hline S11 & _1 & Apr-2010 & 16.0 & 16.0 & 9.6 & 9.6 & 5.0 & 40 & 12.5 & 7.5 \\
\hline \multirow[t]{2}{*}{$\mathrm{S} 12$} & _1 & Sep-2013 & 32.0 & 32.0 & 2.7 & 1.4 & 3.5 & 92 & 3.8 & 0.3 \\
\hline & -2 & - & & - & & 1.3 & & & & \\
\hline
\end{tabular}

LT Life time

lower variability of $d_{90}$ for the downstream reaches underlines that the sediment framework of Aurlandselva was fluvial formed in an alluvial environment. However, some outliers (reach 1,2 and 4) indicate non-fluvial sediments in the various stretches due to rock fall or out-washed glacial deposits (see supplementing material).

Numerical modelling

The findings of the two-dimensional depth-averaged sediment transport modelling using the mobile layer of spawning gravel and the stable layer of coarse-grained framework are presented in Figs. 7 and 8. In Fig. 7 a comparison between the monitoring and the modelling concerning the spatial extent $\left(\mathrm{m}^{2}\right)$ of gravel distribution was made. The results show a good agreement of $R^{2}=0.77$ for field-mapped spatial extent of deposited gravel up to an area of $100 \mathrm{~m}^{2}$ and for one single restoration spot up to $200 \mathrm{~m}^{2}$. However, there was a clear overestimation of erosion rates for S7 and S10 with more than a doubling in the spatial extent of distributing gravel after partial erosion and re-deposition of sediments. The deviations are emphasized in 


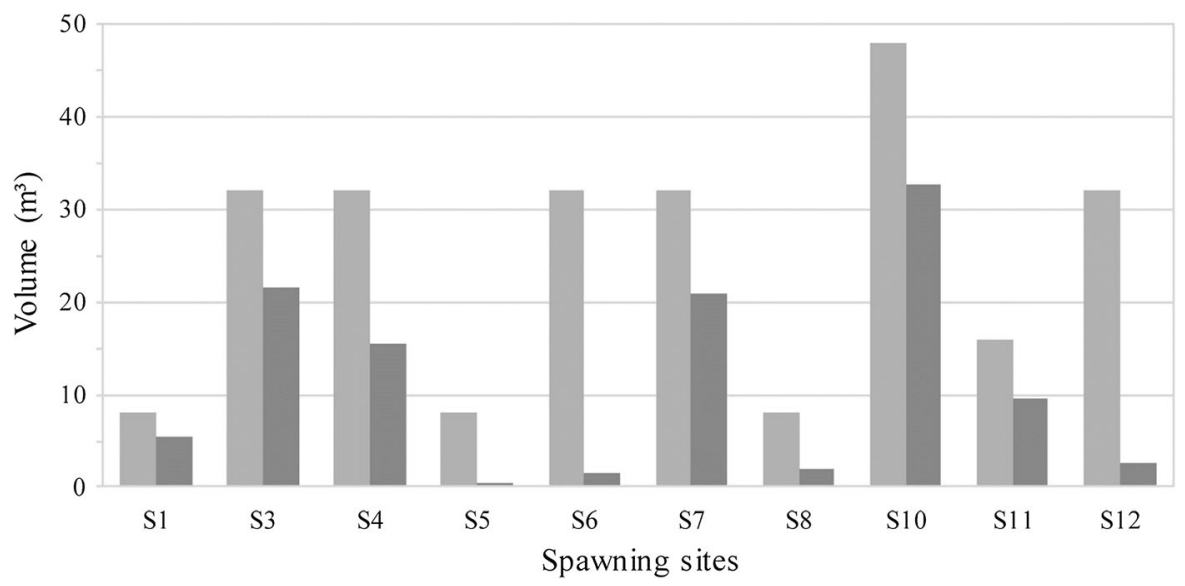

Fig. 4 Comparison of the deposited volume at spawning sites at the date of placement (light grey bars) compared to the GPS-mapped distribution (dark grey bars)

(a)

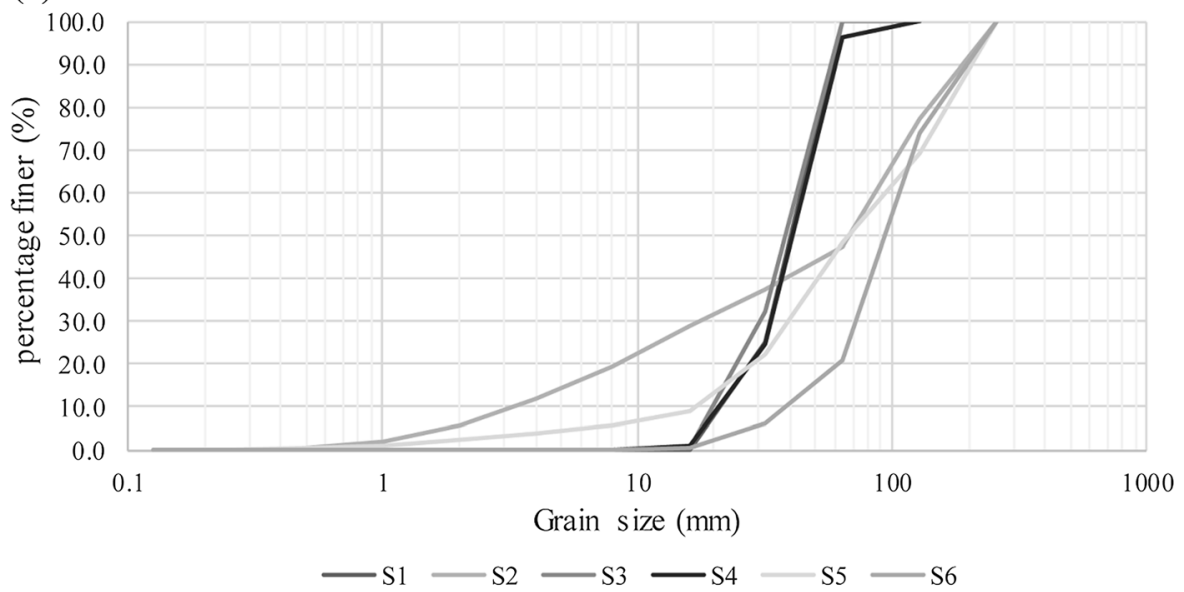

(b)

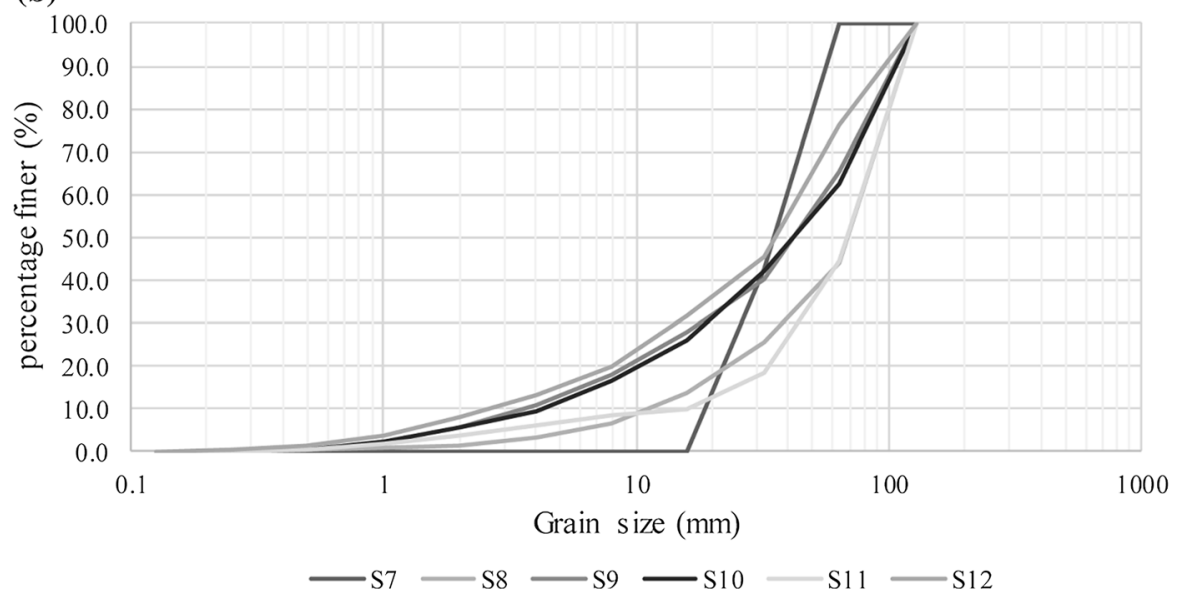

Fig. 5 Grain size distributions of sampled, artificially placed gravel at the various spawning sites a spawing sites 1-6, b spawning sites 7-12 


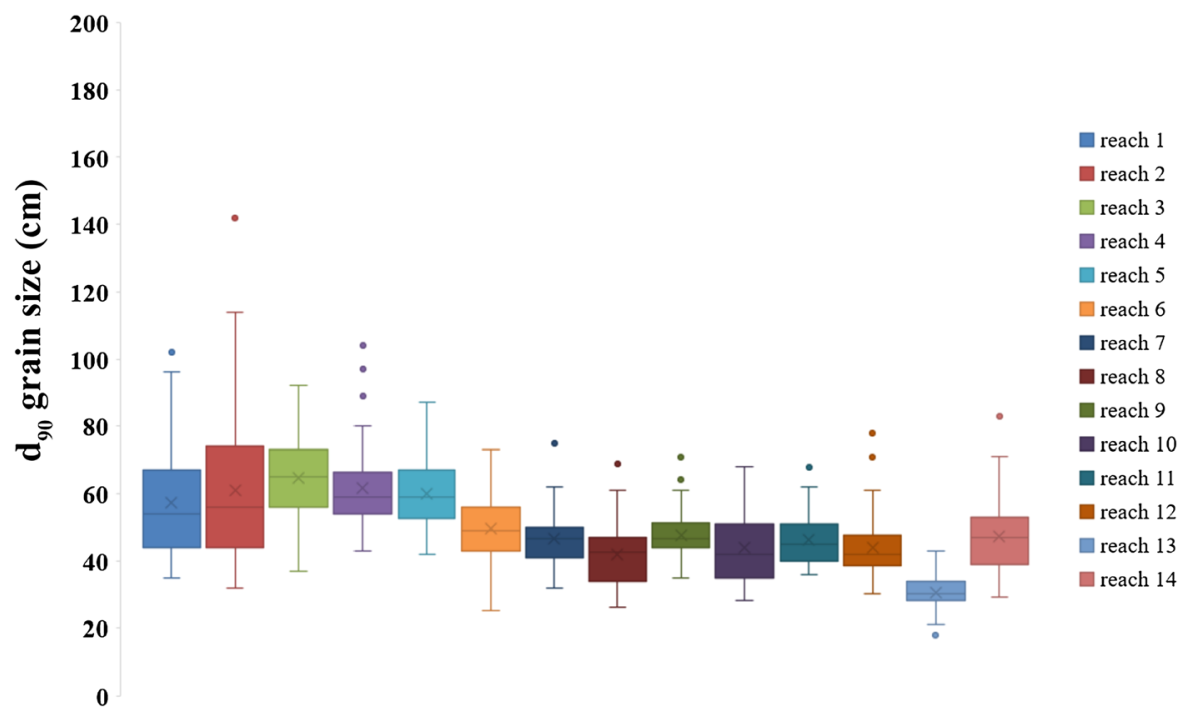

Fig. 6 Boxplots of the $d_{90}$ measurements in Aurlandselva for various reaches; flow direction from left to right

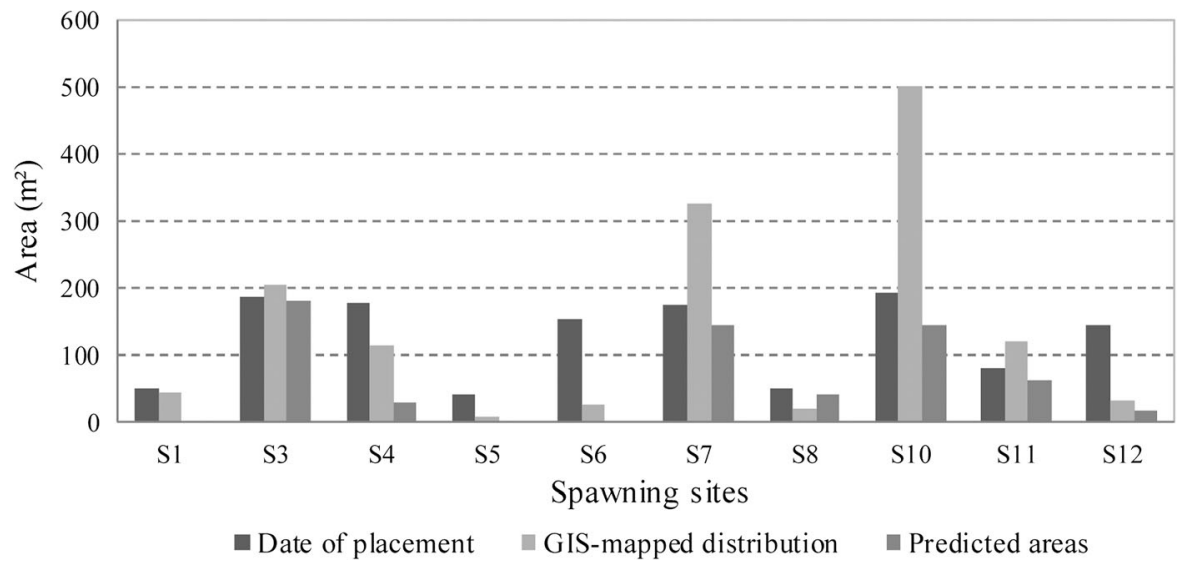

Fig. 7 Comparison of the spatial extent of investigated spawning sites $(n=12)$ at the date of placement (black bars) compared to the GPS-mapped distribution (light grey bars) and

Fig. 7 due to the comparison of the three scenarios: (i) area of gravel placement, (ii) area of monitored (measured) gravel distribution and (iii) area of modelled gravel distribution. Only minor good agreements between monitoring and modelling were given (S3, S8 and S11). Most of the data showed clear deviations between the monitored and modelled spatial distribution of gravel (Fig. 7). On the one hand, for S1, S5 and S6, a total wash out of the gravel was predicted by the two-dimensional depth-averaged sediment transport model (Fig. 7, Table 4). On the other hand, especially for those sites where field-mapped data showed predicted areas by the two-dimensional depth-averaged sediment transport model (dark grey bars)

erosion and re-distribution of gravel due to high discharges (S7 and S10), the model predicted almost no erosion on these sites.

Due to the partially low quality of prediction by the numerical modelling (Fig. 7) and the coarse surrounding roughness elements (see supplementing material), the determined bed coarseness ration (BCR) delivers interesting results. Comparing the grain size of the introduced spawning gravel $(n=12)$ (Table 2$)$ to the sediment framework of the river bottom, the $d_{50}$ (spawning gravel) to the $d_{90}$ (river bottom substrate) deviate by a factor 10 or even higher. Thus, this means 


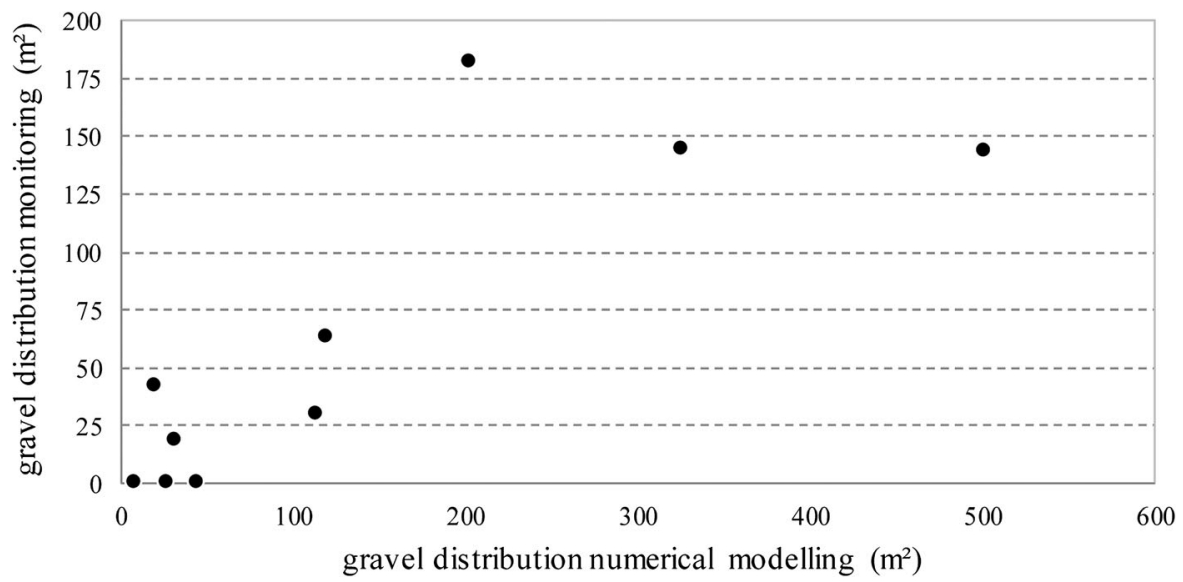

Fig. 8 Comparison of measured and predicted area distribution of spawning gravel for 2015; predicted distribution by twodimensional depth-averaged numerical modelling

Table 4 Development of the spatial extent of the various spawning habitats after deposition and the overformed areas in 2015 including the predicted areas of change by the twodimensional depth-averaged sediment transport model

\begin{tabular}{|c|c|c|c|c|c|c|}
\hline \multicolumn{7}{|c|}{ Development of spawning habitats } \\
\hline \multirow[t]{2}{*}{ Habitat } & \multirow[t]{2}{*}{ Sub. } & \multirow[t]{2}{*}{ Deposition } & \multicolumn{2}{|l|}{2015} & \multicolumn{2}{|l|}{ modelling } \\
\hline & & & Area total $\left(\mathrm{m}^{2}\right)$ & Sub-area $\left(\mathrm{m}^{2}\right)$ & Area total $\left(\mathrm{m}^{2}\right)$ & Sub-area $\left(\mathrm{m}^{2}\right)$ \\
\hline S1 & $\_1$ & Apr-2010 & 45 & 45 & - & - \\
\hline S2 & \multicolumn{2}{|l|}{$\_1$} & \multicolumn{2}{|c|}{ Nat. spawning site } & \multicolumn{2}{|c|}{ Nat. spawning site } \\
\hline \multirow[t]{2}{*}{ S3 } & $\ldots 1$ & Apr-2010 & \multirow[t]{2}{*}{203} & 63 & \multirow[t]{2}{*}{181} & 100 \\
\hline & $\_^{2}$ & Apr-2010 & & 140 & & 81 \\
\hline \multirow[t]{6}{*}{ S4 } & $\_1$ & Apr-2010 & \multirow[t]{6}{*}{114} & 92 & \multirow[t]{6}{*}{30} & - \\
\hline & $\_^{2}$ & Apr-2010 & & 16 & & 17 \\
\hline & _3 & Apr-2010 & & 6 & & 7 \\
\hline & -4 & Apr-2010 & & - & & - \\
\hline & ${ }_{-}^{5}$ & Apr-2010 & & - & & - \\
\hline & _6 & Apr-2010 & & - & & 6 \\
\hline S5 & -1 & Sep-2013 & 8 & 8 & - & - \\
\hline \multirow[t]{4}{*}{ S6 } & -1 & Sep-2013 & \multirow[t]{4}{*}{27} & 9 & \multirow[t]{4}{*}{-} & - \\
\hline & $\_2$ & Sep-2013 & & 8 & & - \\
\hline & ${ }^{3} 3$ & Sep-2013 & & 10 & & - \\
\hline & -4 & Sep-2013 & & - & & - \\
\hline \multirow[t]{2}{*}{ S7 } & -1 & Apr-2010 & \multirow[t]{2}{*}{326} & 140 & \multirow[t]{2}{*}{144} & 75 \\
\hline & $\_2$ & Apr-2010 & & 186 & & 69 \\
\hline S8 & $\_1$ & Apr-2010 & 20 & 20 & 42 & 42 \\
\hline S9 & \multicolumn{2}{|l|}{$\_1$} & \multicolumn{2}{|c|}{ Nat. spawning site } & \multicolumn{2}{|c|}{ Nat. spawning site } \\
\hline \multirow[t]{3}{*}{ S10 } & $\_1$ & Apr-2010 & \multirow[t]{3}{*}{501} & 22 & \multirow[t]{3}{*}{143} & 31 \\
\hline & -2 & Sep-2011 & & 271 & & 61 \\
\hline & ${ }^{3}$ & Sep-2011 & & 208 & & 51 \\
\hline S11 & $\_1$ & Apr-2010 & 120 & 120 & 63 & 63 \\
\hline \multirow[t]{2}{*}{$\mathrm{S} 12$} & $\_1$ & Sep-2013 & \multirow[t]{2}{*}{32} & 14 & \multirow[t]{2}{*}{18} & 18 \\
\hline & $\_2$ & - & & 18 & & - \\
\hline
\end{tabular}




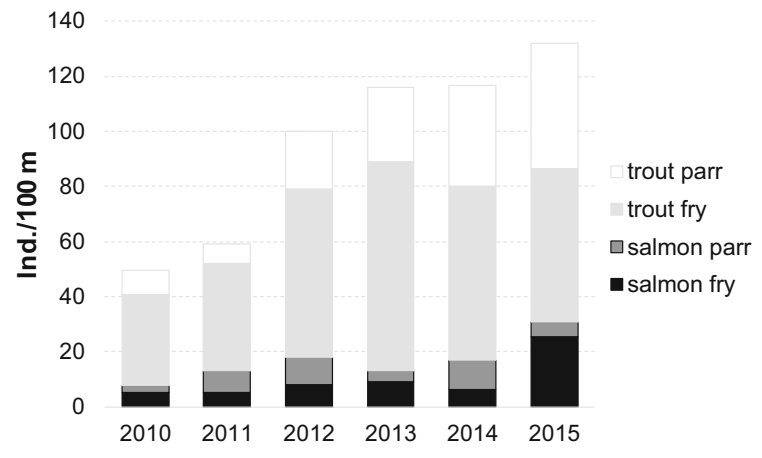

Fig. 9 Densities of juvenile salmonids (ind. $100 \mathrm{~m}^{-2}$ ) at six artificial spawning sites in the Aurlandselva 2010-2015

that a very high micro-topographic variability is given which is not reflected in the bathymetry of the twodimensional depth-averaged hydrodynamic-numerical model applied in this study, which needs to be discussed.

\section{Biological monitoring}

After the completion of spawning grounds in 2010, spawning of anadromous brown trout and their spawning redds were observed on all 6 sites each year. The number of redds registered per site varied between 3 and 10 (median 5). Redds and egg pockets may have been overlooked due to methodological limitations and changes in gravel surface, e.g. in case of superimposition (overspawning). Trout fry $(<$ $7 \mathrm{~cm}$, "0+") densities increased from 33 to 76 ind. $100 \mathrm{~m}^{-2}$ until 2013 and dropped thereafter to 56 in 2015 (Fig. 9). Trout parr (7-15 cm) densities decreased from 9 in 2010 to 7 ind.in $2011100 \mathrm{~m}^{-2}$ and increased steadily thereafter to 45 ind. $100 \mathrm{~m}^{-2}$ in 2015. Atlantic salmon juvenile densities varied between 8 and 31 ind. $100 \mathrm{~m}^{-2}$ in the 6 years with no clear trend, but with highest record in 2015 (Fig. 9).

\section{Discussion}

The restoration of spawning habitats by artificial gravel placement is an important measure to overcome the bottleneck of salmonid fish reproduction in regulated rivers of Western Norway (Barlaup et al., 2008; Fjeldstad et al., 2012; Pulg et al., 2018). In the post-glacial environment, alluvial sediments are partly limited by geology and sediment production rates
(Hauer \& Pulg, 2018). Thus, artificial gravel dumping is one of the most important mitigation measures if salmonid stocks have to be enhanced in regulated rivers. From a hydraulic perspective, artificial gravel dumping, which has frequently been applied below dams (Sear \& DeVries, 2008; Pasternack, 2008; Brown \& Pasternack, 2009), affect geomorphic units (meso-scale) and, consequently, hydraulic patterns on the micro-scale (Pasternack, 2008). However, in contrast to such effects of gravel dumping on hydraulic characteristics like changes in meso- and micro-scale flow velocity distributions, we have observed that the existing channel governed the hydromorphic response rather than the added gravels in the investigated Aurlandselva. Here, the microtopographical elements remained constant (rough river bed) and had an impact on the dumped gravel sheets (not vise-versa). By calculating a ratio of the introduced gravel and the coarse framework $\left(d_{\mathrm{m}}\right.$ gravel $/ d_{90}$ framework), we suggest that such impacts can be quantified for steep gradient or non-fluvial rivers (Hauer \& Pulg, 2018)—that are otherwise different to forecast, compared to gravel bed rivers. This is a novel aspect in terms of spawning habitat restoration in such environments, similar to the work of Brown \& Pasternack (2014) for gravel bed rivers.

Biological monitoring of the spawning habitats in the Aurlandselva showed that all of the spawning sites were used by sea trout which dominates the fish biomass of the river although spawning Atlantic salmon was also observed. The fish have reproduced on the sites $(n=12)$ in each spawning season after the construction, as long as the sites existed. The density of juvenile fish increased significantly during 2009-2015. Average juvenile density at six of the test sites was 50 ind. $\mathrm{m}^{-2}$ in 2009 and 125 ind. $\mathrm{m}^{-2}$ in 2015 (77\% trout, $23 \%$ salmon). Thus, the measures were considered as successful (Pulg et al., 2018). The decline of fry after a peak in 2013 can be explained by density-dependent effects, e.g. competition due to the increase of parr densities and total density (Jonsson \& Jonsson 2011). Anadromous brown trout is dominating the fish stock in the river (Pulg et al., 2013b). Thus, low and varying densities of Atlantic salmon juveniles can be explained by a lower amount of salmon spawners and an uneven distribution of their spawning in the monitoring period. Increased fry densities in some years indicate however that also Atlantic salmon reproduced on the spawning sites. 
The selected grain size for the restoration project also aligns with other studies of successful spawning habitat restoration (e.g. Kondolf \& Wolman, 1993; Barlaup et al., 2008). Moreover, the monitoring showed that spawning sites do not degrade due to fine sediment accumulation similar to spawning restoration projects downstream of dams (e.g. Merz et al., 2006; Wheaton et al., 2010), as described for many other rivers with lower gradients (Pulg et al., 2013a, b) and higher sediment supply rates (Hauer, 2015), negative impacts were solely given due to the scouring during floods. According to the stability and life span of the artificial spawning sites, the results showed that there is a high variability of scouring and estimated life span (between 1 and 10 years, Table 3). Ugedal et al. (2019) compiled an overall balance of spawning habitats between 2010 and 2015 over the entire course of Aurlandselvi and determined an average linear life time of spawning gravel areas of around 18 years (Table 5). This life span is longer than our predicted ones because the authors measured the total spawning area in the river including new spawning patches that were formed by washed out gravel downstream from the dumping sites. Assuming a linear development, the dumping sites we observed can be used by spawning fish for between 1.5 and 15.5 years.

From a modelling perspective, it is possible that the accuracy of the Digital Elevation Model (lack of micro-topographical roughness elements) is one reason for low accuracy in the prediction and the overestimation of erosional processes. The DTM was cross-sectional based, with a lack in reflecting the micro-topographical roughness (compare to $d_{90}$ results in Fig. 6). According to Mosselman \& Le (2016), the topography of the riverbed is the most important boundary condition for a morphodynamic model. Furthermore, in the model no corrections according to El Kadi Abderrezzak et al. (2016) were carried out with regard to exposure/protection; and therefore, sometimes in the very small test areas (about $50 \mathrm{~m}^{2}$ ), an increased expression of re- arrangement processes occurs. Nevertheless, in recent years, the role of turbulence and fluctuating parameters such as unsteady velocities, pressures, drag and lift forces has been widely acknowledged (Schmeeckle et al., 2007; Smart \& Habersack, 2007; Diplas et al., 2008; Celik et al., 2013; Sindelar \& Smart, 2016; Hauer et al., 2019). Mainly in physical laboratory studies, research on the sediment transport dynamics (e.g. incipient motion, delta formation, deposition) was based on critical turbulent forces and impulse (Celik et al., 2013), critical local approach velocity (Schmeeckle et al., 2007) and grid turbulence imposed on the flow (Wan Mohtar \& Munro, 2013). However, the contribution of turbulent processes is not reflected in the applied (Meyer-Peter \& Müller, 1948) or other commonly used sediment transport formulas (e.g. Shields, 1936; Meyer-Peter \& Müller, 1948; Rickenmann, 2001). This has to be seen as additional aspects as it has already been stated as uncertainty in applying the Meyer-Peter \& Müller (1948) formula (compare to Wong \& Parker, 2006).

Sufficient turbulence information is lacking in hydraulic models, not only in the applied two-dimensional depth-averaged model of the presented study but also in three-dimensional e.g. RANS software (Reynolds-Average-Navier-Stokes), which average the turbulence on structured or unstructured grids. Beside the on-site-derived data about stability of gravel placement in the Aurlandselva, physical laboratory studies underline the complexity of threedimensional turbulence processes with an impact on sediment dynamics. Exemplarily, in a flume experiment on spawning habitat restoration for Norwegian rivers, the implementation of boulders was tested to prevent the erosion of artificial spawning gravel (see supplementing material) in a scale of 1:20. Interestingly, boulder placements exhibited on the one hand hiding effects (compare to Parker, 1990) on spawning gravel, which can yield in gravel stability, but on the other hand, under the same hydraulic framework, but with slight modification of the boulder placement, they

Table 5 Prediction of spawning habitat life span

\begin{tabular}{lllll}
\hline $\begin{array}{l}\text { Spawning area after gravel } \\
\text { placement }\left(\mathrm{m}^{2}\right)\end{array}$ & $\begin{array}{l}\text { Spawning area } \\
2015\left(\mathrm{~m}^{2}\right)\end{array}$ & $\begin{array}{l}\text { Average age in } \\
\text { (Years) }\end{array}$ & $\begin{array}{l}\text { Percentage of spawning } \\
\text { area 2015 }\end{array}$ & $\begin{array}{l}\text { Predicted life span linear } \\
\text { (Years) }\end{array}$ \\
\hline 6099 & 4993 & 3.3 & $82 \%$ & 18.4 \\
\hline
\end{tabular}


resulted in a total wash out of the deposited substrate (see supplementing material). These, findings are supported by flume experiments of Hauer et al. (2019) in which an increase in turbulence intensity (\%) was identified as a driving parameter for magnitude in sediment transport. Similar to those scaled experiments, the surface substrate in the Aurlandselva contains high variability in largest grain sizes $\left(d_{90}\right)$ (compare to Fig. 6) and thus a high variability in micro-topographic roughness. This has a strong impact on the near-bed turbulence intensity (compare to Hauer et al., 2019) and thus the erosional forces for sediment transport like the deposited spawning gravel. This might be the reason why the model prediction of gravel distribution failed for most of the sites in comparison to good examples of two-dimensional depth-averaged numerical modelling in solely fluvial environments with lower largest grains $\left(d_{90}\right)$ of surface layer composition. Suggestions on the quality of twodimensional hydrodynamic-numerical models according to $d_{90}$ have already been given in Hauer et al. (2011), in which limited use for such models at grain sizes larger than $20 \mathrm{~cm}\left(d_{90}\right)$ was postulated.

The presented ratio (BCR) between (i) mean diameter of artificial introduced spawning gravel and (ii) the micro-topographical roughness of the river bed $\left(d_{90}\right)$ allows to reflect more detailed information on this substrate variability and can be seen as an indicator for how high turbulence as well as possible hiding effects (compare to Parker, 1990) might impact artificially implemented spawning sites. Based on Hauer et al. (2019) a BCR > 3-5 (depending on the height of gravel deposits) might be seen as a threshold criteria where local turbulence may impact the stability (positively and negatively) of spawning habitats and when numerical modelling reaches invalidity. However, these numbers are just based on a single physical laboratory experiment and need to be validated and probably adjusted in future. These micro-topographical roughness impacts were not recognized so far though they may have strong effects on river restoration success and especially gravel bed spawning rehabilitation. Hauer et al. (2015) documented for seven spawning habitat restoration sites in Norway that backwater step models were useful to evaluate both spawning habitat suitability and bed stability based on friction slope $\left(\mathrm{S}_{\mathrm{f}}\right)$ variations on the meso- and macro-unit scale. Moreover, it was documented that sites with $S_{\mathrm{f}}<0.002$ have a suitable and stable flow range during low and high flow conditions, respectively. These findings, however, were mostly derived on fluvial formed river stretches with grain sizes $d_{90}<20 \mathrm{~cm}$ (e.g. Matreelva, Teigdalselva). Therefore as one further central outcome, it is recommended to apply the BCR index to check if numerical modelling is applicable to predict the success of spawning gravel remediation. In such rivers with unfavourable BCR index, hydraulic modelling may be a useful tool to identify river sections sufficient for spawning rehabilitation on a reach scale (e.g. cross-section based), but the placement of gravel should rather be supported by detailed field mapping on a mesohabitat and microhabitat scale including local hydraulic details like hiding effects of boulders.

\section{Conclusions}

Twelve artificial spawning gravel placements for Atlantic salmon and sea trout in the Aurlandselva were investigated. Substantial variation in the erosion of the artificial gravel ranged from 32 to $95 \%$. The changes strongly depended on the on-site microhydraulic characteristics during flood events. The erosion and its variability, however, could not have been predicted by numerical modelling. This can be explained by limited representation of turbulence in the numerical codes and the lack of micro-topographical information in the modelling bathymetry. Thus, for channels with high micro-topographical roughness (dominated by boulders and cobbles, steep mountain rivers or non-fluvial rivers) with $d_{90}$ to bankfull depth $>0.5$ and complex three-dimensional flow along the river surface, field mapping is a recommended method for the monitoring of spawning gravel and the estimation of dynamics and life time. Here, remote sensing technologies like UAV (high-resolution aerial pictures) may be appropriate as a cost-effective methodology in low-turbidity rivers. Based on UAV pictures, the largest grains can also be detected as important information for the application of novel spawning coefficients.

Acknowledgements Open access funding provided by University of Natural Resources and Life Sciences Vienna (BOKU). The financial support by the Austrian Federal Ministry of Science, Research and Economy and the National Foundation of Research, Technology and Development is gratefully acknowledged. The field studies were funded by E-Co Energi 
and CEDREN through "EnviDorr"- and "Tiltaksprosjekt". Moreover, parts of the study were financially supported by STATKRAFT and E-Co Energi during the project "SAMS Sustainable Sediment Management in regulated rivers". Thanks to Bjørn Otto Donnum for logistic support and providing data. Moreover, the supportive work of Angelika Schoder and Daniel Pucher is gratefully acknowledged.

Open Access This article is licensed under a Creative Commons Attribution 4.0 International License, which permits use, sharing, adaptation, distribution and reproduction in any medium or format, as long as you give appropriate credit to the original author(s) and the source, provide a link to the Creative Commons licence, and indicate if changes were made. The images or other third party material in this article are included in the article's Creative Commons licence, unless indicated otherwise in a credit line to the material. If material is not included in the article's Creative Commons licence and your intended use is not permitted by statutory regulation or exceeds the permitted use, you will need to obtain permission directly from the copyright holder. To view a copy of this licence, visit http://creativecommons.org/licenses/by/4.0/.

\section{References}

Abderrezzak, K. E. K., A. D. Moran, P. Tassi, R. Ata \& J. M. Hervouet, 2016. Modelling river bank erosion using a 2D depth-averaged numerical model of flow and non-cohesive, non-uniform sediment transport. Advances in Water Resources 93: 75-88.

Armstrong, J. D., P. S. Kemp, G. J. A. Kennedy, M. Ladle \& N. J. Milner, 2003. Habitat requirements of Atlantic salmon and brown trout in rivers and streams. Fisheries Research 62(2): 143-170.

Barlaup, B. T., S. E. Gabrielsen, H. Skoglund \& T. Wiers, 2008. Addition of spawning gravel-a means to restore spawning habitat of atlantic salmon (Salmo salar L.), and Anadromous and resident brown trout (Salmo trutta L.) in regulated rivers. River Research and Applications 24: 543-550.

Bjornn, T. C. \& D. W. Reiser, 1991. Habitat requirements of salmonids in streams. American Fisheries Society Special Publication 19: 138.

Bogen, J. 2015. Map of sediment production in Norwegian catchments. https://www.nve.no/hydrologi/erosjon-ogsedimenttransport/sedimentkilder-og-sedimentbudjett/.

Brayshaw, A. C., L. E. Frostick \& I. Reid, 1983. The hydrodynamics of particle clusters and sediment entrapment in coarse alluvial channels. Sedimentology 30: 137-143.

Brown, R. A. \& G. B. Pasternack, 2008. Engineered channel controls limiting spawning habitat rehabilitation success on regulated gravel-bed rivers. Geomorphology 97: $631-654$.

Brown, R. A. \& G. B. Pasternack, 2009. Comparison of methods for analysing salmon habitat rehabilitation designs for regulated rivers. River Research and Applications 25: $745-772$.
Brown, R. A., \& G. B. Pasternack, 2014. Hydrologic and topographic variability modulate channel change in mountain rivers. Journal of hydrology 510: 551-564.

Brunner, G.W., 1998. HEC-RAS: River Analysis System. Unpublished Users Manual, Version 2.2. U.S. Army Corps of Engineers, CA.

Buffington, J. M., D. R. Montgomery \& H. M. Greenberg, 2004. Basin-scale availability of salmonid spawning gravel as influenced by channel type and hydraulic roughness in mountain catchments. Canadian Journal of Fisheries and Aquatic Sciences 61: 2085-2096.

Celik, A. O., P. Diplas \& C. L. Dancey, 2013. Instantaneous turbulent forces and impulse on a rough bed: implications for initiation of bed material movement. Water Resources Research 49: 2213-2227.

Costello, M. J., 2009. How sea lice from salmon farms may cause wild salmonid declines in Europe and North America and be a threat to fishes elsewhere. Proceedings of the Royal Society of London B: Biological Sciences 276: 3385-3394.

Diplas, P., C. L. Dancey, A. O. Celik, M. Valyrakis, K. Greer \& T. Akar, 2008. The role of impulse on the initiation of particle movement under turbulent flow conditions. Science 322: 717-720.

Faugli, P. E., 2008. The Aurland catchment area-the watercourse and hydropower development. Norsk Geografisk Tidsskrift - Norwegian Journal of Geography 48: 3-7.

Fjeldstad, H. P., B. T. Barlaup, M. Stickler, S. E. Gabrielsen \& K. Alfredsen, 2012. Removal of weirs and the influence on physical habitat for salmonids in a Norwegian river. River Research and Applications 28: 753-763.

Forseth, T., B. T. Barlaup, B. Finstad, P. Fiske, H. Gjøsæter, M. Falkegård, A. Hindar, T. A. Mo, A. H. Rikardsen, E. B. Thorstad, L. A. Vøllestad \& V. Wennevik, 2017. The major threats to Atlantic salmon in Norway. ICES Journal of Marine Science 74: 1496-1513.

Fleming, I. A., 1996. Reproductive strategies of Atlantic salmon: ecology and evolution. Reviews in Fish Biology and Fisheries 6: 379-416.

Gaeuman, D., 2014. High-flow gravel injection for constructing designed in-channel features. River Research and Applications 30: 685-706.

Gaeuman, D., R. Stewart, B. Schmandt \& C. Pryor, 2017. Geomorphic response to gravel augmentation and highflow dam release in the Trinity River, California. Earth Surface Processes and Landforms 42: 2523-2540.

Gard, M., 2006. Modeling changes in salmon spawning and rearing habitat associated with river channel restoration. International Journal of River Basin Management 4: 1-11.

Ghanem, A., P. Steffler \& F. Hicks, 1996. Two-dimensional hydraulic simulation of physical habitat conditions in flowing streams. Regulated Rivers Research and Management 12: 185-200.

Gibson, R. J., R. L. Haedrich \& C. M. Wernerheim, 2005. Loss of fish habitat as a consequence of inappropriately constructed stream crossings. Fisheries 30(1): 10-17.

Gregory, S. V. \& P. A. Bisson, 1997. Degradation and loss of anadromous salmonid habitat in the Pacific Northwest. In Stouder, D. J., P. A. Bisson \& R. J. Naiman (eds.), Pacific Salmon \& Their Ecosystems. Springer, Boston: 277-314. 
Huitfeld-Kaas, H., 1918. Ferskvandsfiskenens utbredelse og innvandring i Norge, med et tillæg om krebsen. Centraltrykkeriet, Oslo.

Hauer, C., 2015. Review of hydro-morphological management criteria on a river basin scale for preservation and restoration of freshwater pearl mussel habitats. Limnologica 50: 40-53.

Hauer, C. \& H. Habersack, 2009. Morphodynamics of a 1000-year flood in the Kamp River, Austria, and impacts on floodplain morphology. Earth Surface Processes and Landforms 34: 654-682.

Hauer, C. \& U. Pulg, 2018. The non-fluvial nature of Western Norwegian rivers and the implications for channel patterns and sediment composition. Catena 171: 83-98.

Hauer, C., G. Unfer, M. Tritthart, E. Formann \& H. Habersack, 2011. Variability of mesohabitat characteristics in rifflepool reaches: testing an integrative evaluation concept (FGC) for MEM-application. River Research and Applications 27: 403-430.

Hauer, C., G. Unfer, H. Habersack, U. Pulg \& J. Schnell, 2013. Bedeutung von Flussmorphologie und Sedimenttransport in Bezug auf die Qualität und Nachhaltigkeit von Kieslaichplätzen. KW Korrespondenz Wasserwirtschaft 4/13: 189-197.

Hauer, C., U. Pulg, S. E. Gabrielsen \& B. T. Barlaup, 2015. Application of step-backwater modelling for salmonid spawning habitat restoration in Western Norway. Ecohydrology 8: 1239-1261.

Hauer, C., P. Lichneger, J. Holzinger, J. Schobesberger, H. Habersack \& C. Sindelar, 2019. Ripple dynamics over various micro-topographical roughness elements and their implications for river management. River Research and Applications 35: 601-610.

Hedger, R. D., O. H. Diserud, O. T. Sandlund, L. Saksgård, O. Ugedal \& G. Bremset, 2018. Bias in estimates of electrofishing capture probability of juvenile Atlantic salmon. Fisheries Research 208: 286-295.

Heggberget, T. G., 1988. Timing of spawning in Norwegian Atlantic salmon (Salmo salar). Canadian Journal of Fisheries and Aquatic Sciences 45: 845-849.

Jensen, A. J., B. O. Johnsen \& L. M. Sættem, 2008. Anadromous brown trout and Atlantic salmon in the Aurland watercourse. Norsk Geografisk Tidsskrift - Norwegian Journal of Geography 48: 45-50.

Jonsson, B. \& N. Jonsson, 2011. Ecology of Atlantic Salmon and Brown Trout. Springer, Habitat as a template for life histories: 708.

Jonsson, N., B. Jonsson \& L. P. Hansen, 1991. Energetic cost of spawning in male and female Atlantic salmon (Salmo salar L.). Journal of Fish Biology 39: 739-744.

Kemp, P., D. Sear, A. Collins, P. Naden \& I. Jones, 2011. The impacts of fine sediment on riverine fish. Hydrological Processes 25: 1800-1821.

Klemetsen, A., P. A. Amundsen, J. B. Dempson, B. Jonsson, N. Jonsson, M. F. O'connell \& E. Mortensen, 2003. Atlantic salmon Salmo salar L., brown trout Salmo trutta L. and Arctic charr Salvelinus alpinus (L.): a review of aspects of their life histories. Ecology of Freshwater Fish 12: 1-59.

Kondolf, G. M., 1997. PROFILE: hungry water: effects of dams and gravel mining on river channels. Environmental Management 21: 533-551.
Kondolf, G. M. \& M. G. Wolman, 1993. The sizes of salmonid spawning gravels. Water Resources Research 29: 2275-2285.

Krkošek, M., J. S. Ford, A. Morton, S. Lele, R. A. Myers \& M. A. Lewis, 2007. Declining wild salmon populations in relation to parasites from farm salmon. Science 318: 1772-1775.

Lane, S. N., 1998. Hydraulic modelling in hydrology and geomorphology: a review of high resolution approaches. Hydrological Processes 12: 1131-1150.

Leclerc, M., A. Boudreault, T. A. Bechara \& G. Corfa, 1995. Two-dimensional hydrodynamic modeling: a neglected tool in the instream flow incremental methodology. Transactions of the American Fisheries Society 124: 645-662.

Lisle, T. E. \& J. Lewis, 1992. Effects of sediment transport on survival of salmonid embryos in a natural stream: a simulation approach. Canadian Journal of Fisheries and Aquatic Sciences 49: 2337-2344.

Louhi, P., A. Mäki-Petäys \& J. Erkinaro, 2008. Spawning habitat of Atlantic salmon and brown trout: general criteria and intragravel factors. River Research and Applications 24: $330-339$.

MacKenzie, L. G., B. C. Eaton \& M. Church, 2018. Breaking from the average: why large grains matter in gravel-bed streams. Earth Surface Processes and Landforms 43: 3190-3196.

Merz, J. E. \& C. L. K. Ochikubo, 2005. Effects of gravel augmentation on macroinvertebrate assemblages in a regulated California river. River Research and Applications 21: 61-74.

Merz, J. E., G. B. Pasternack \& J. M. Wheaton, 2006. Sediment budget for salmonid spawning habitat rehabilitation in a regulated river. Geomorphology 76: 207-228.

Meyer-Peter, E., \& R. Müller, 1948. Formulas for bed-load transport. IAHSR 2nd Meeting, Stockholm, Appendix 2. IAHR.

Moir, H. J., C. Soulsby \& A. Youngson, 1998. Hydraulic and sedimentary characteristics of habitat utilized by Atlantic salmon for spawning in the Girnock Burn, Scotland. Fisheries Management and Ecology 5: 241-254.

Mosselman, E. \& T. B. Le, 2016. Five common mistakes in fluvial morphodynamic modeling. Advances in Water Resources 93: 15-20.

Naden, P. S. \& A. C. Brayshaw, 1987. Small-and medium-Scale Bedforms in Gravel-Bed Rivers. Environment and process, River channels: 249-271.

Nicholas, A. P. \& D. E. Walling, 1997. Modelling flood hydraulics and overbank deposition on river floodplains. Earth Surface Processes and Landforms 22: 59-77.

Nujic, M., 1999. Praktischer Einsatz eines hochgenauen Verfahrens für die Berechnung von tiefengemittleten Strömungen. Mitteilungen des Institutes der Bundeswehr München, Nr: 64.

Nujic, M., 2008. Hydro_GS - Tutorial. 18.

Obruca, W. \& C. Hauer, 2017. Physical laboratory analyses of intergravel flow through brown trout redds (Salmo trutta fario) in response to coarse sand infiltration. Earth Surface Processes and Landforms 42: 670-680.

Olsson, E. G. A., G. Austrheim \& S. N. Grenne, 2000. Landscape change patterns in mountains, land use and 
environmental diversity, Mid-Norway 1960-1993. Landscape Ecology 15: 155-170.

Parker, G., 1990. Surface-based bedload transport relation for gravel rivers. Journal of Hydraulic Research 28: 417-436.

Pasternack, G. B. 2008. Spawning habitat rehabilitation: advances in analysis tools. American Fisheries Society Symposium, Vol. 65.

Pasternack, G. B., C. L. Wang \& J. Merz, 2004. Application of a 2D hydrodynamic model to reach-scale spawning gravel replenishment on the lower Mokelumne river, California. River Research and Applications 20: 205-225.

Powell, D. M., 2014. Flow resistance in gravel-bed rivers: progress in research. Earth-Science Reviews 136: 301-338.

Pulg, U., B. T. Barlaup, K. Sternecker, L. Trepl \& G. Unfer, 2013a. Restoration of spawning habitat of brown trout in a regulated chalk stream. River Research and Applications 29: 172-182.

Pulg, U., B. T. Barlaup, H. Skoglund, T. Wiers, S.-E. Gabrielsen, Eirik, \& S. Normann, 2013b. Gyteplasser og sideløp i Aurlandsvassdraget. Technical report. UNI Miljø LFI rapport nr. 221. NORCE LFI, Norwegian Research Centre, Bergen

Pulg, U., B. T. Barlaup, H. Skoglund, G. Velle, S.-E. Gabrielsen, S. Stranzl, E. E. Olsen, B. G. Lehmann, T. Wiers, B. Skår, E. Nordmann, H.-P. Fjeldstad, F. Kroglund, 2018. Tiltakshåndbok for bedre fysisk vannmiljø: God praksis ved miljøforbedrende tiltak i elver og bekker. Technical report. NORCE LFI rapport 296. NORCE, Bergen.

Pulg, U., K. W. Vollset \& R. J. Lennox, 2019. Linking habitat to density-dependent population regulation: how spawning gravel availability affects abundance of juvenile salmonids (Salmo trutta and Salmo salar) in small streams. Hydrobiologia 841: 13-29.

Rickenmann, D., 2001. Comparison of bed load transport in torrents and gravel bed streams. Water Resources Research 37: 3295-3305.

Rosenfeld, J., 2003. Assessing the habitat requirements of stream fishes: an overview and evaluation of different approaches. Transactions of the American Fisheries Society 132: 953-968.

Rosenqvist, I. T., 1978. Alternative sources for acidification of river water in Norway. Science of the Total Environment 10: $39-49$.

Rubin, J. F. \& C. Glimsäter, 1996. Egg-to-fry survival of the sea trout in some streams of Gotland. Journal of Fish Biology 48: 585-606.

Sauterleute, J. F., R. D. Hedger, C. Hauer, U. Pulg, H. Skoglund, L. E. Sundt-Hansen \& O. Ugedal, 2016. Modelling the effects of stranding on the Atlantic salmon population in the Dale River, Norway. Science of the Total Environment 573: 574-584.

Sawyer, A. M., G. B. Pasternack, H. J. Moir \& A. A. Fulton, 2010. Riffle-pool maintenance and flow convergence routing observed on a large gravel-bed river. Geomorphology 114: 143-160.

Schmeeckle, M. W., J. M. Nelson \& R. L. Shreve, 2007. Forces on stationary particles in near-bed turbulent flows. Journal of Geophysical Research 112(F2): F02003.

Sellheim, K., C. Watry, B. Rook, S. Zeug, J. Hannon, J. Zimmerman, K. Dove \& J. Merz, 2015. Juvenile salmonid utilization of floodplain rearing habitat after gravel augmentation in a regulated river. River Research and Applications 32: 610-621.

Sear, D. A. \& P. DeVries, (eds), 2008. Salmonid Spawning Habitat in Rivers: Physical Controls, Biological Responses, and Approaches to Remediation, vol. 65. American Fisheries Society, Bethesda, 376 pp. (Symposium, 65).

Shields, A., 1936. Anwendung der Aenlichkeitsmechanik und der Turbulenzforschung aufdie Geschiebebewegung. Mitteilungen der Preussischen Versuchsanstalt fur Wasserbau and Schiffbau, Berlin.

Sindelar, C. \& G. M. Smart, 2016. Transition flow in step-pool systems: pressure distributions and drag forces. Journal of Hydraulic Engineering 142(10): 04016035.

Smart, G. M. \& H. M. Habersack, 2007. Pressure fluctuations and gravel entrainment in rivers. Journal of Hydraulic Research 45: 661-673.

Soulsby, C., A. F. Youngson, H. J. Moir \& I. A. Malcolm, 2001. Fine sediment influence on salmonid spawning habitat in a lowland agricultural stream: a preliminary assessment. Science of the Total Environment 265: 295-307.

Thorstad, E. B., F. Økland, K. Aarestrup \& T. G. Heggberget, 2008. Factors affecting the within-river spawning migration of Atlantic salmon, with emphasis on human impacts. Reviews in Fish Biology and Fisheries 18: 345-371.

Tonina, D. \& J. M. Buffington, 2007. Hyporheic exchange in gravel bed rivers with pool-riffle morphology: laboratory experiments and three-dimensional modeling. Water Resources Research 43: 1-16.

Tvede, A. M., 2008. Discharge, water temperature and glaciers in the Aurland river basin. Norsk Geografisk Tidsskrift Norwegian Journal of Geography 48: 23-28.

Ugedal, O., U. Pulg, H. Skoglund, J. Charmasson, E. O. Espedal, J. G.Jensås, S. Stranzl, A. Harby \& T. Forseth, 2019. Sjøaure oglaks i Aurlandsvassdraget 2009-2018. Reguleringseffekter,miljødesign og tiltak. Technical report, NINA Rapport 1716. 156 p. Norsk institutt for naturforskning. Trondheim

Walling, D. E., \& B. Webb, (Eds), 1996. Erosion and Sediment Yield: Global and Regional Perspectives: Proceedings of an International Symposium Held at Exeter, UK, from 15 to 19 July 1996 (No. 236). IAHS.

Wan Mohtar, W. H. M. \& R. J. Munro, 2013. Threshold criteria for incipient sediment motion on an inclined bedform in the presence of oscillating-grid turbulence. Physics of Fluids 25: 015103.

Wilcock, P. R., G. M. Kondolf, W. V. Matthews \& A. F. Barta, 1996. Specification of sediment maintenance flows for a large gravel-bed river. Water Resources Research 32: 2911-2921.

Wheaton, J. M., G. B. Pasternack \& J. E. Merz, 2004. Spawning habitat rehabilitation-I. Conceptual approach and methods. International Journal of River Basin Management 2: 3-20.

Wheaton, J. M., J. Brasington, S. E. Darby, J. Merz, G. B. Pasternack, D. Sear \& D. Vericat, 2010. Linking geomorphic changes to salmonid habitat at a scale relevant to fish. River Research and Applications 26: 469-486.

Wolman, M. G., 1954. A method of sampling coarse river-bed material. EOS, Transactions American Geophysical Union 35(6): 951-956. 
Wong, M. \& G. Parker, 2006. The bedload transport relation of Meyer-Peter and Muller overpredicts by a factor of two. Journal of Hydraulic Engineering 132: 1159-1168.

Yuzyk, T. R., 1986. Bed material sampling in gravel-bed streams. Doctoral dissertation, Sediment Survey Section, Water Survey of Canada, Water Resources Branch, Inland Waters Directorate.

Zeug, S. C., K. Sellheim, C. WatryB, J. Rook, J. Hannon, D. Zimmerman, D. Cox \& J. Merz, 2014. Gravel augmentation increases spawning utilization by anadromous salmonids: a case study from California, USA. River Research and Applications 30: 707-718.

Publisher's Note Springer Nature remains neutral with regard to jurisdictional claims in published maps and institutional affiliations. 